\title{
The Role of Community Engagement in Higher Education: Convergence Relating to Knowledge Growth- a Practical Model and Guidelines
}

\author{
Chala Wata Dereso ${ }^{1}$, Harrison Sunil Kumar Domathoti' ${ }^{2}$, Ram Gopal N. $\mathrm{Ch}^{3}$ \\ ${ }^{1}$ President, Bule Hora University, Ethiopia \\ ${ }^{2}$ Professor, Department of Management, Bule Hora University, Ethiopia \\ ${ }^{3}$ Associate Professor, Department of Mathematics, Bule Hora University, Ethiopia
}

\begin{abstract}
As attention to community engagement nurtures and it is important that instructors, students, and community associatescomprehend how it is conceptualized. This paper representsresults from a qualitative review with academics and community engagement superintendents nationwide with esteem to how they conceptualize community service.This article reiterates the definition and thoughtfulnessof communityservice as one of the crucialareas of Higher Education Establishments in Ethiopia.Itsseizures the significance of a proper methodologyin the direction of community serviceand contributes about a applied method through the multifacetedinteraction between academic societies and communities. The present study will launch a healthierawareness of the community, its traditions, and its cultural programs as anallinclusive platform for consideratelocalsocieties. Theproposed recommendationsmay facilitate community engagement architects to prepare andimplement community servicesschemes effectively.
\end{abstract}

Keywords : Community service, Higher education institutions, Guidelines, Ethiopia community

\section{Introduction}

Educational organizations or universities main goals are preparingthe students more intellectual minds and hire the motivated teachers and initiate the research, scholar activity and national recognition for developing innovative ideas to grow selectively, serve the region and achieve distinction(Bishaw \& Melesse, 2017)(Bhagwan, 2017).The main purpose of present study is to investigate the higher educational organizations or universities'approachability towards community engagement, using the experience of fast-growing higher education institution in Bule Hora as a model-based case study. The focus of study aimed to various objectives of higher educational institutions by the Ethiopian Higher Education Act to giveawareness to local community development as a third pillar of service to society along with other two pillars such as teaching and learning, and research(Antonio et al., 2000).

The Ethiopian higher education environment is basically hampered by a combination of academic, socio-political, and economic challenges and all those are resulted in much instability situations. Due to this reason, engagement with local community bodiesretains the potential to drive out by instable the disciplinebasedrestrictions of higher educational institutions to a multifaceted concern with common issues. Therefore, community engagement has postulated that its disparate partnerships with communities can exploit and nurture discovery, learning and innovation so that higher education can become further entrenched within community and can become a partner with anxiety for societal wellbeing.

In any nation there is a need for universities and educational organizations to dedicate themselves towards transforming into socially responsible civic institutions through their institutional cultures and policies(Lazarus, 2007). This claimcome together into a range of interests that academics began engaging in. Through their teaching, research, community-responsive clinical care, and service(Negusse et al., 2007). Universities also began documenting their contributions towards enhancing learning, innovative teaching practices and scholarship that had positive benefits for communities(Chatio et al., 2019). Civic engagement was therefore conceived to benefit and improve the place of higher education, though forms of community engagement have become rooted in Ethiopia and especially in Bule Hora region, discourse and empirical research related to engagement has only begun emerging. 
Some experts around the globe given some statements and suggestions about university and community service linkages. Aslin and Brown (2004) (Aslin \& Brown, 2004) had mentioned that a community does not only refer to a specific geographic region, butit may also be a community of interest and responsibility. Muller(Muller, 2009) had stated that that community services were a contextual activity and those were highly depending on the task and fortes of the university and the state of regional development in the area and the surrounding local community bodies. Furco and Muller (Furco \& Miller, 2009) stated that most universities define community engagement within the context of the institutional plan, saying that it was a core priority. However, Holland (2005) had noted however that institutional approaches to engagement vary according to their unique missions and regional settings such as rural or urban campuses. Moreover, such factors are crucial to understanding how engagement is understood and expressed within a state's larger cultural, demographic, political, economic, and historical context.

Present study explores in a practical and real sense, how responsive to community engagement or services is this particular university i. e. Bule Hora University. Based on universities continued contributionto the local community bodies, some sense observations arefound that the footprint of community service activities wounds across the broader university community in a broad level. Study is also focused to investigate the various aspects of responsibilities of universities to engage in different cultural and social activities for the local communities' developments. Importance research questions related to the community engagement are also addressed.

\section{Background}

According to the Ethiopian Higher Education Act of Proclamation No. 1152/2019(Proclamation, n.d.), universities or educational organizations in this country have a principal role of supportingfor creating optimal opportunities for teaching \&learning, and the innovation and distribution of knowledge among the community bodies(Mabokela \& Mlambo, 2017). The act further identifies three different critical pillars central to the role of these organizationslike Teaching and Learning, Research and Community commitment.Any university or higher educational organizations may perform various activities to enrich the leaving standards of people of the nation(Menon \& Suresh, 2020). Figure 1 is illustrated to various approaches or activities which university may use to initiate the changes in society. Society as a community always tries to expose various high-tech changes and real-world applications of knowledge and allied areas. Most of the universities are most focusing on education and research and ignoring the community activities, this leaving unbelievably bad impact on communities in that country or nation(Amano et al., 2012). As people cannot apply the technology without guidance or proper instructions. Technology is like a knife which has two dissimilar varieties of piercing edges, it may also have opposite effect on welfare, if is misused. Therefore, it is the responsibility of higher educational organizations to provide opinions, directions, and correct supervision about technology to the community.

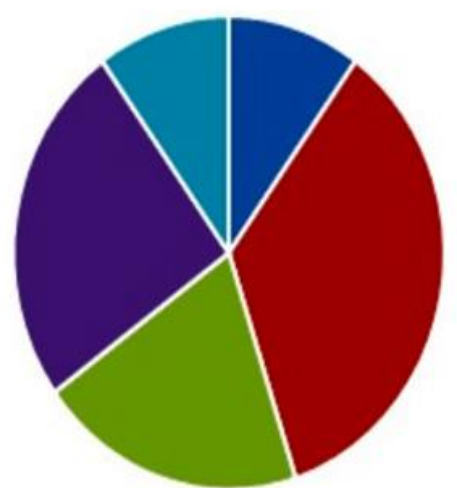

-Others - Education = Education \& Research $\|$ Research $=$ Communty Services

Figure 1 Schematic diagram showing different activities in universities (Nasution et al., 2020) 


\section{Rationale}

The main drive of the present study is to investigate the responsiveness to community engagement by a higher education in Ethiopia country using a case study of an institution in the province of Bule Hora. The study is not essentially concerned with assessing the impact of the university's community engagement activities. Its main focus is basically on attainmentofimproved understandings of the university ways of responding or not to community engagement as an education pillar. TheIdea isintended to launch how the university responds in terms of policies, funding, structural setting, and general attitude related community service. Study is also keen to guide how the university communicates and its community service program for both internal and external activities.

\section{Typology of Community service}

The typology of community serviceis important task to understand the various activities in a broader context. As pointed out in various literature mentioned earlier that community service can yield several different forms and profiles in the context of Ethiopian higher education systems, with its activities promoting stakeholders and local community bodies in aneffective manner. The students and teachers can participate in a community service initiative which may derive help to learning exercise when the local community receives a service performed depends upon the nature of engagement activity rendered(Nasution et al., 2020). The Community on the other hand may spring benefit from the available resources and facilities which may university system opens up access to communities. Diagram (Figure 2) given below may give the better ideology about various activities which can conduct related to the development of communities through university.

\section{Key Research Questions}

The critical areas of query or question in which research required to respond to are How does the higher education organization determine alertness to community engagement? Some important questions or queries are given below to addressing present study of activities of universities in development of community service (Bhagwan, 2017):

i What are the universities' policies and rules which may initiate activities related community engagement?

ii What organizational structures aims for promoting community service?

iii How are the organizational stakeholders being actively engaged for community development activities?

iv How are community bodies communicated by the university about their required development activities?

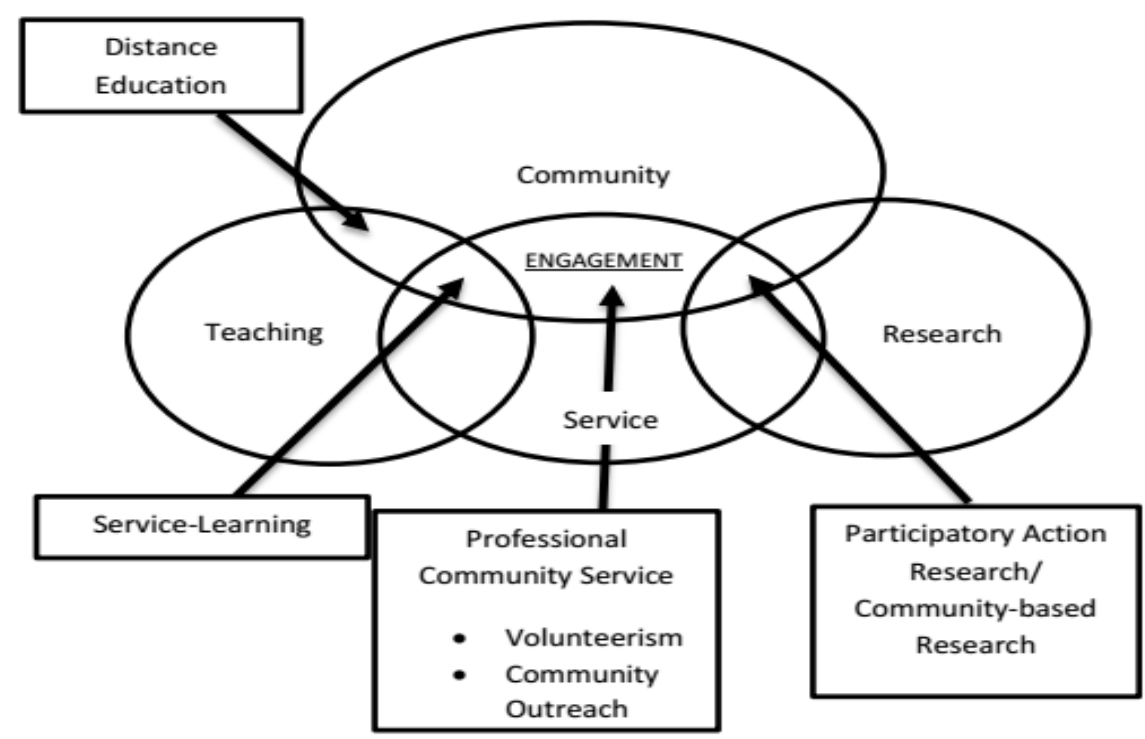


Figure 2 Typology Model of Community Engagement(Sedumedi et al., 2014)

It is clear that first main steps in community service activities should be planned systematically for enhanced results. Universities which established in that regions can be conscious of the subsequent six areas of acquaintance in order to prepare them to understand societies and to manage community rendezvousprograms in culturallypenetrating and bearable ways(Coetzee, 2012):

i acquaintance of the social associations among the communities.

ii knowledge of ethnicities and cultural values of community

iii knowledge of societalvalues in the community

iv information of safety and refugeissues in the community

$\mathrm{v}$ knowledge of well-beingor wellness centers of the community and

vi acquaintance of economic ideals and systems of that particular community.

Universities need to create systematic bonding among the various communities in the regions in the nation. To make or facilitate proper channel; there are some important aspects required to followed and those are stated as follows(Sedumedi et al., 2014):

i facilitation of information related to the internal requirementsoflocal communities

ii easing of information concerning the exterior needs of communityassignation and involvement

iii enabling to establishsettlement and configurationamong various sections incommunities

iv The use of prevailing and new information in the community assignation process and

$\mathrm{v}$ using evidence to market purposes and to ensure maintainable motivation and interest

\section{DISCUSSION}

From the research questions and required facilities for making university and community service linkage, it is stated that many interactive parameters may influence the initiation and conduction of community service activities. Different influencing parameters and it inter connections between the factors are visualized in Figure 3. From the Figure 3, it noted that top portion of the diagram shows the cyclic as well as reciprocal relationship among knowledge, action and change. Various factors like research environment, university or organization, community and practitioner and its significances to participatory translation of knowledge into action in community-based roles are also depicted in Figure 3. From the Figure 3, one can get better awareness about the significant issues which affecting transition from knowledge to action.

The study and analysis of university teachers and their individual values principally determine their level of pledge to community service activities. Teachers who are altruistic, service oriented, and community oriented - regardless of their institution - are very often to participate in community service. Such values also manifest themselves in their preference for studentcentered pedagogy and research interests regarding race and ethnicity(Mabokela \& Mlambo, 2017). Primary investigation from the present study is reveal an interesting challenge for university trying to encourage the integration of community service activities into the educational mission of their institutions. Teachers who were categorized by a strong rational orientation - those who choose academia principally because of the prospects it provides to pursue rational interests - are less likely to be involved in or devoted to civic service. Although, teachers' personal values were particularly important in determining commitment to community service, socialization influences are also some evidence(Amano et al., 2012). Pre-socialization into teacher roles is important for community service activities. Teacher socialized in service-oriented fields like social work and education seem to benefit from their experiences, even when personal values and orientations are held constant to account for possible self-selection effects. 


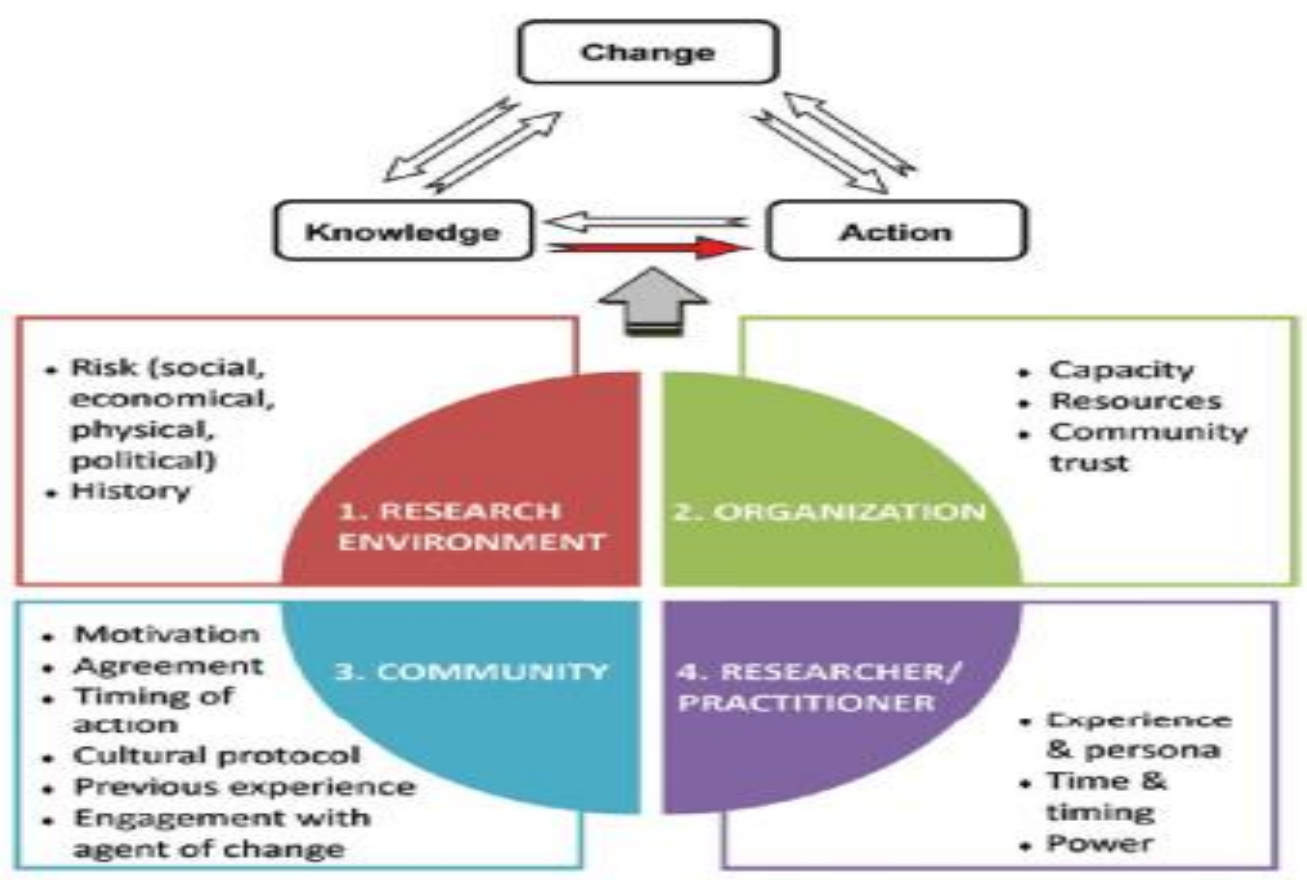

Figure 3 Factors effecting the translation of action oriented community service in higher education organizations

(Tiwari et al., 2014)

\section{Summery}

Based on astudy conducted, it is stated that there is a association between civicservice and university. Universitypolicies to find resolution to problems that are contemporary in thecommunity or precisely present. On the diverse side, the community service is to bondthe university and the community welfares that cannot be unswervinglyassociated byother activities. As designated in the introduction, this article analyzed the problem of the explanation and considerate of the concept community service. It apprehended the reputation of the precisetactic to community assignation and contributed concerning a hands-on method to guide the apprenticeby the awkward and intricate interactionsamongtheoretical societies, communities and other active bodies- each with their own needs, contributions, and prospects to benefit and grow during the progressions of effective community engagement. It became apparent that the wide assortment of aspects that form part of effective community provision activities can be succeeded with great kindliness. It also pronounced, in note, developments and functional methods to monitor academic responsibilitiesof teachers who will act as community packageimplementers.

\section{Future scope of work}

- In order to discourse the main,investigative question and its secondary questions arevealingpatternwill implement.

- To search and illustrateone specific case, numerous data compilationdevices and supplierswillbe employed in the data congregation.

- A practical case study explore design will employed to obtainpainstakingawarenessrelated toprojectedissues and to help out in cracking the problem with ease.

- In amalgamation with the aforementioned questionnaires and interviews, and toward the datacollection stage, core groups will be directed with current registered students and teachers to participate in these communityunits.

\section{References}

Amano, A., Gebeyehu, A., \& Birhanu, Z. (2012). Institutional delivery service utilization in Munisa Woreda, South East Ethiopia: a community based 
cross-sectional study. BMC Pregnancy and Childbirth, 12, 1-6. https://doi.org/10.1186/14712393-12-105

Antonio, A. L., Astin, H. S., \& Cress, C. M. (2000). Community service in higher education: A look at the nation's faculty. Review of Higher Education, 23(4), 373-398 https://doi.org/10.1353/rhe.2000.0015

Aslin, H., \& Brown, V. (2004). Towards Whole of Community Engagement: a practical toolkit. 1146.

http://www.citeulike.org/group/1702/article/10942 74

Bhagwan, P. R. (2017). Towards a conceptual understanding of community engagement in higher education in South Africa. Perspectives in Education, 35(1), 171-185. https://doi.org/10.18820/2519593x/pie.v35i1.13

Bishaw, A., \& Melesse, S. (2017). Historical Analysis of the Challenges and Opportunities of Higher Education in Ethiopia. Higher Education for the Future, 4(1), 31-43. https://doi.org/10.1177/2347631116681212

Chatio, S., Welaga, P., Tabong, P. T. N., \& Akweongo, P. (2019). Factors influencing performance of community-based health volunteers' activities in the Kassena-Nankana Districts of Northern Ghana. PLoS ONE, 14(2), 1-12. https://doi.org/10.1371/journal.pone.0212166

Coetzee, E. (2012). Community engagement by Higher Education Institutions - a practical model and guidelines. Africa Education Review, 9(3), 501517.

https://doi.org/10.1080/18146627.2012.742669

Furco, A., \& Miller, W. (2009). Issues in benchmarking and assessing institutional engagement. New Directions for Higher Education, 2009(147), 4754. https://doi.org/10.1002/he.357

Lazarus, J. (2007). Embedding Service Learning in South African Higher Education: The Catalytic Role of the CHESP Initiative. Education as Change, 11(3), 91-108. https://doi.org/10.1080/16823200709487182

Mabokela, R. O., \& Mlambo, Y. A. (2017). Access and equity and South African higher education: A review of policies after 20 years of democracy. Comparative Education Review, 61(4), 780-803. https://doi.org/10.1086/693913

Menon, S., \& Suresh, M. (2020). Synergizing education, research, campus operations, and community engagements towards sustainability in higher education: a literature review. International Journal of Sustainability in Higher Education, 21(5), 1015-1051. https://doi.org/10.1108/IJSHE03-2020-0089

Muller, J. (2009). 1 This paper published here for the HERANA project is a version of a paper written in response to Martin Hall's commissioned paper for the Council on Higher Education. Hall, M. Community engagement in South African higher education. Both papers are to be . 7, 1-13.

Nasution, M. K. M., Tulus, Munir, E., \& Onrizal. (2020). Without research, no community service. Journal of Physics: Conference Series, 1542(1). https://doi.org/10.1088/1742-6596/1542/1/012071

Negusse, H., McAuliffe, E., \& MacLachlan, M. (2007). Initial community perspectives on the Health Service Extension Programme in Welkait, Ethiopia. Human Resources for Health, 5, 1-5. https://doi.org/10.1186/1478-4491-5-21

Proclamation. (n.d.). Revised HE Proclamation 11522019.pdf.

Sedumedi, M. D., Brien, S. F. O., \& Searle, R. (2014). Collegeof humanities school of education higher education ' $s$ responsiveness to community engagemenT: A case of one higher education institution in Kwazulu Natal Master of Education Higher Education in the School of Education . University of KwaZulu Nat. December.

Tiwari, R., Lommerse, M., \& Smith, D. (2014). M2 models and methodologies for community engagement. M2 Models and Methodologies for Community Engagement, August, 1-284. https://doi.org/10.1007/978-981-4585-11-8

R. Sathish, R. Manikandan, S. Silvia Priscila, B. V. Sara and R. Mahaveerakannan, "A Report on the Impact of Information Technology and Social Media on Covid-19," 2020 3rd International Conference on Intelligent Sustainable Systems (ICISS), Thoothukudi, India, 2020, pp. 224-230, doi: 10.1109/ICISS49785.2020.9316046.

Manikandan, R and Dr.R.Latha (2017). "A literature survey of existing map matching algorithm for navigation technology. International journal of engineering sciences \& research technology", 6(9), 326-331.Retrieved September 15, 2017.

A.M. Barani, R.Latha, R.Manikandan, "Implementation of Artificial Fish Swarm Optimization for Cardiovascular Heart Disease" International Journal of Recent Technology and Engineering (IJRTE), Vol. 08, No. 4S5, 134-136, 2019. 